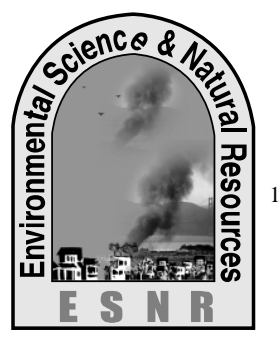

\title{
Effectiveness of Some IPM Packages Consisting of Chemical and Non Chemical Components for Suppressing Pod Borer and Aphid in Summer Country Bean
}

\author{
M. R. U. Miah ${ }^{1}$, N. Barman ${ }^{1}$, M. Z. Alam ${ }^{1}$, K. Yesmin ${ }^{2}$ and M. Ahmad ${ }^{3 *}$
}

${ }^{1}$ Department of Entomology, Bangabandhu Sheikh Mujibur Rahman Agricultural University, ${ }^{2}$ Cotton Development Board, Sreepur, Gazipur, ${ }^{3}$ Department of Entomology, BAU, Mymensingh

*Corresponding author: masum_bau2006@yahoo.com

\begin{abstract}
An experiment was conducted in the experimental farm of Bangabandhu Sheikh Mujibur Rahman Agricultural University (BSMRAU), Gazipur to evaluate the efficacy of IPM packages for suppressing aphid and pod borer of summer country bean BARI Seem-3. In case of aphid, among the different IPM packages, $\mathrm{P}_{4}$ [comprising mechanical control (hand picking) and 4 sprays of admire 50 SP (imidacloprid) @ $1 \mathrm{ml} \mathrm{l}^{-1}$ of water at 7 days interval] had minimum inflorescence infestation (4.99), whereas untreated control plot $\mathrm{P}_{7}$ totally overturned. In case of pod borer, among the IPM packages, $\mathrm{P}_{5}$ [comprising mechanical control, hand picking with 4 sprays of ripcord $10 \mathrm{EC}$ (cypermethrin) @ $1 \mathrm{ml} \mathrm{l}^{-1}$ of water at 7 days interval] ensured minimum inflorescence and pod infestation (by number and weight) and pod diameter with the lowest pest incidence $(4.59 \%)$. In consideration of the economic analysis of the different management packages for controlling pod borer of country bean, the highest BCR ratio (4.28) was recorded in the $\mathrm{P}_{5}$ [comprising mechanical control, hand picking with 4 sprays of ripcord $10 \mathrm{EC}$ (cypermethrin) @ $1 \mathrm{ml} \mathrm{l}^{-1}$ of water at 7 days interval] followed by 3.76 in $\mathrm{P}_{6}$. However, based on marketable pod yield and BCR, hand picking with 4 sprays of ripcord 10 EC (cypermethrin)@ $1 \mathrm{ml} \mathrm{l}^{-1}$ of water at 7 days interval may be considered as the most effective option.
\end{abstract}

Keywords: Aphids, IPM packages, Management and Pod borer

\section{Introduction}

Country Bean [Lablab purpureus L. (Sweet)] has become the most important and popular leguminous crop in Bangladesh covers a significant acreage after Brinjal and Tomato. Generally, it is also known as income generating crop in our country. This crop is also important for its atmospheric nitrogen fixation (Kalra, 1979). It is grown on approximately 11000 ha across the country during the winter season, yielding an average of $4.53 \mathrm{t}$ of fresh pods per ha for a total yield of about $50000 \mathrm{t}$ (Anonymous, 2004). Begum (1993) stated that the crop probably originated in Indo-Bengal subcontinent or Africa or in both places. This bean commonly known as "seem" in Bangladesh. The fresh pods and green seeds are eaten boiled or used in curries. Mature seeds are used as pulse, often as soup. Mature seeds are occasionally sun-dried and stored for use as vegetables. This bean is also grown for fodder and as a cover crop. The leaves and seeds contain 20-28\% protein, with a well-balanced amino acid composition (Schaffhausen, 1963). It contains tyrosinase enzyme, which has potential use in the treatment of hypertension. In addition, the pod also provides vitamins such as vitamin $\mathrm{A}$, vitamin $\mathrm{C}$, riboflavin, thiamine and minerals like magnesium, calcium, phosphorus, potassium, iron, sulfur and sodium (Gopalan et al., 1982). In Bangladesh, it occupies 40992 acres, of which annual production is 88581 t in 2009-2010 (Anonymous, 2010). Previously more than $80 \%$ of the country beans were produced in the Rabi season while less than $20 \%$ were grown in Kharif season (Hossain and Awrangzeb, 1992). The summer variety of country bean play vital role to meet up off season vegetable deficiency. Due to severe attack of various insect pests, significant yield loss of country bean occurs every year. According to Alam (1969), country bean is attacked by nine different insect species and one species of mite. Both aphids and pod borers are polyphagus and they occur throughout the year with variable levels of infestation. Pod borer infestation occurs more frequently at flowering stage. Maruca testulalis infest the pod and feed by making hole. Aphis craccivora Koch is the most serious pest of bean plants from seedling to pod bearing stage, causing considerable yield loss (Dixon, 1987). Due to severe of infestation plants fail to give flowering and pods setting resulting in $20-40 \%$ yield loss (Islam, 2008).

Botanical extracts or non chemical materials (neem oil, neem leaf extract, bishkatali, and ash) are safe to apply, unique in action and can easily be processed. It has little or no effect against beneficial spiders, ladybird beetles, parasitoid wasp and predatory mites and insects (Walter, 1999). Most of the botanical extracts are also cost effective and readily available near to the farmers in time. As a result botanical pesticides are becoming popular day by day. Now a day, these are being used against many insects including aphid and pod borer. Use of botanical extract against insect pest control is however, a recent approach to insect pest management and it has drawn special attention to the Entomologist all over the world. In Bangladesh, only a few attempts have been made to evaluate botanical extracts plus chemical insecticide side by side against insect's pest (Karim, 1995) .Under the above perspective, the present study was undertaken in order to compare damage severity due to pod borer and aphid on BARI Seem-3, to find out most effective tactics out of different IPM packages consisting of chemical and non chemical components against pod borer and aphid attacking country bean and to compare chemical and nonchemical methods for the management of pod borer and aphid to reduce the infestation for better yield.

\section{Materials and Methods}

The details of the materials needed for the study along with the methodology are given in the following subheadings 


\section{Experimental site and experimental period}

The experiment was carried out at the experimental field of the department of Entomology Bangabandhu Sheikh Mujibur Rahman Agricultural University, Gazipur. The experimental site was situated at $24.09 \mathrm{~N}$ latitude and 90.26 E longitudes with an elevation of 8.4 meter from the sea level.

\section{Soil and climate}

The soil type of the experimental field belongs to the shallow red brown terrace type under Salna Series of Madhupur tract of agro ecological zone (AEZ) 28 which is characterized by silty clay with $\mathrm{pH}$ value of 5.8 and CEC 20.06.

\section{Land preparation}

The soil was well prepared and good tilth was ensured for a very good crop production. The land was divided into 21 equal plots $(3 \mathrm{~m} \times 2 \mathrm{~m})$ with plot to plot distance of $0.5 \mathrm{~m}$ and block to block distance is $1.0 \mathrm{~m}$.

\section{Pit preparation}

Pits were prepared 10 days before transplanting of seedlings. The pits were finally prepared in such a way that these pits remained at least $10 \mathrm{~cm}$ above the ground level to avoid water stagnation. Each plot contains only one row with 5 pits $(60 \mathrm{~cm}$ distance from pit to pit) per row.

\section{Design of experiment and layout}

The experiment was laid out in a randomized complete block design (RCBD) with three replications. The whole area of experimental field was divided into 3 blocks and each block was again divided into 7 unit plots.

\section{Preparation of plots}

Individual plots were prepared with basal dose of chemical fertilizers and cow dung was applied with the help of a spade. At the same time pre-sowing final weeding was done to facilitate seed germination and minimize crop weed competition.

\section{Collection of seed, seedling raising and transplantation}

The seeds of BARI Seem-3 were collected from the Olericulture Division of Horticulture Research Centre of BARI, Gazipur. Seedlings were transplanted in the pits with the entire soil ball. The seedlings were watered until they got established. Out of two seedlings per pit, one was removed 14 days after transplanting.

\section{Mechanical control}

For mechanical control, infested pods were cut with sharp knife and destroyed weekly soon after collecting the data starting from first appearance of shoot infestation and continued till last harvest. All the infested pods were buried in soil immediately after collection.

\section{Treatments}

Comparative effectiveness of the following seven IPM packages in reducing the pod borer infestation on summer country bean (BARI Seem-3) was evaluated $\mathrm{P}_{1}=$ Mechanical control (hand picking) and 4 sprays of neem leaf extract@50ml $1^{-1}$ of water at 7 days interval

$\mathrm{P}_{2}=4$ sprays of biskatali leaf extract @ $50 \mathrm{ml} \mathrm{l}^{-1}$ of water at 7 days interval

$\mathrm{P}_{3}=4$ sprays of sabion 60 EC (diazinon) @ $1 \mathrm{ml} \mathrm{l}^{-1}$ of water at 7 days interval

$\mathrm{P}_{4}=$ Mechanical control (handpicking) and 4 sprays of admire $50 \mathrm{SP}$ (imidacloprid) @ $1 \mathrm{ml} \mathrm{l}^{-1}$ of water at 7 days interval

$\mathrm{P}_{5}=$ Mechanical control (handpicking) and 4 sprays of ripcord $10 \mathrm{EC}$ (cypermethrin) @ $1 \mathrm{ml} \mathrm{l}^{-1}$ of water at 7 days interval

$\mathrm{P}_{6}=$ Mechanical control (handpicking) and 4 sprays of neem oil @ $5 \mathrm{ml} \mathrm{l}^{-1}$ of water at 7 days interval and

$\mathrm{P}_{7}=$ Control (Untreated)

Spraying was started from first flower initiation of the country bean.

\section{Processing plant product}

Green and fresh leaves of bishkatali (Polygonum orientale L.) and neem (Azadirechta indica A.) were collected from BSMRAU campus, Gazipur. Neem oil was collected from BARI, Joydebpur. Gazipur. Required amount of fresh bishkatali and neem leaves were taken and soaked overnight in water. Leaves were chopped and grounded in a grinding machine with sufficient water. Ground leaves were mixed with water followed by gentle stirring. Then the mixture was filtered to get the formulated botanical insecticide. Neem oil was directly mixed in water to spray in the field.

\section{Data collection and calculation}

Data were collected per plot basis. Data collection was started at flower initiation up to final harvest and it was collected up to 10 harvesting period. The data were recorded on inflorescence infestation, pod infestation (by number and by weight) by aphid and pod borer larvae, pod diameter and yield $\left(\mathrm{t} \mathrm{h} \mathrm{h}^{-1}\right.$ ) and were obtained. Economic analysis of different packages was done by calculating BCR (Benefit Cost Ratio).

\section{Percent inflorescence infestation by number}

Number of infested flower was counted from total flowers and percent flower infestation was calculated by using the following formula:

Number of the infested inflorescence

$\%$ Inflorescence infestation=

\section{Percent pod infestation by number}

Number of infested pod was counted from total pods

\section{Total number of inflorescence}

X 100

and percent pod infestation was calculated as follows Number of the infested pod

Total number of pod

110 


\section{Percent pod infestation by weight was calculated using the following formula}

Weight of the infested pod

$\%$ Pod infestation $($ weight $)=$

\section{Economic analysis}

The economic analysis or benefit cost ratio (BCR) was calculated on the basis of total expenditure of the respective packages along with the total return from that particular treatment. In this study BCR was calculated for a hectare of land.

\section{Management cost}

This was calculated by adding the costs incurred for labors and inputs for each packages.

\section{Gross return}

Finally the benefit cost ratio (BCR) was calculated by the formula

Adjusted net return

Benefit cost ratio $(\mathrm{BCR})=$
Total pod weight

This was measured by multiplying the total yield by the unit price of chemical and unit price of non chemical product at that time.

\section{Net return}

Net return was calculated by subtracting management cost from gross return.

\section{Adjusted net return}

The adjusted net return was determined by subtracting the net return gained from untreated control plot from the net return of a package.

\section{Results and Discussion}

The findings of the experiment are described in following section with tables and figures which are necessary for appropriate discussions as follows

\section{Effect of different IPM packages in suppressing in terms of number of inflorescence infestation}

No significant variation was observed by number of infested and healthy inflorescence per plot at 3 days after spraying (DAS) in suppressing aphid of country bean utilizing different IPM packages and presented in Table1. It revealed from the Table 1 that in case of number of healthy inflorescence there was no significant difference among IPM packages. However, significant variation was observed in the number of infested inflorescence due to the application different packages. It is also evident from the Table 1 that significantly the lowest infestation was occurred in case of number of infested inflorescence (4.99) from the plots treated with package $\mathrm{P}_{4}$ but statistically comparable to those of $\mathrm{P}_{1}$ (5.98) and $\mathrm{P}_{5}(5.14)$ which was followed by package $\mathrm{p}_{3}(6.14), \mathrm{P}_{2}(8.26)$ and $\mathrm{P}_{6}(8.65)$ but the latter two are not significantly different. On the other hand the highest number of infested inflorescence (10.67) was found in $\mathrm{P}_{7}$ which was untreated control. It can be said from result of the study that the effectiveness among the packages, the performance of $\mathrm{P}_{4}$ was the best followed by $\mathrm{P}_{5}$, $\mathrm{P}_{1}$ and $\mathrm{P}_{3}$. The percent of infested inflorescence ranged from $16.69 \%$ to $33.09 \%$. Significantly the highest percent $(33.09 \%)$ of infested inflorescence was recorded from the untreated control plot which was statistically different from all other packages. On the other hand the lowest percent of infested inflorescence $(16.69 \%)$ was obtained from Package $\mathrm{P}_{5}$ treated plot which was statistically similar to those of $\mathrm{P}_{1}(20.53 \%), \mathrm{P}_{3}(20.10 \%)$ and $\mathrm{P}_{4}(18.89 \%)$. These are followed by $\mathrm{P}_{2}(27.32 \%)$ having statistically comparable result with $\mathrm{P}_{6}(27.57 \%)$. From Table 1, it may be opined that there was no significant difference among the package $\mathrm{P}_{1}, \mathrm{P}_{3}, \mathrm{P}_{4}$ and $\mathrm{P}_{5}$. But those treatments perform better than those of $\mathrm{P}_{2}$ and $\mathrm{P}_{6}$. All the packages were found to be better than untreated control $\left(\mathrm{P}_{7}\right)$. Sharma (1998) found that cypermethrin was the most effective insecticide against aphid on chickpea, though they did not test this insecticide as component of any IPM package.

Table 1. Effect of different IPM packages in suppressing aphids in terms of number of inflorescence infestation per plot

\begin{tabular}{|l|l|l|l|l|}
\hline Treatments & $\begin{array}{c}\text { No. of healthy } \\
\text { inflorescence at 3 DAS }\end{array}$ & $\begin{array}{c}\text { No. of infested } \\
\text { inflorescence at 3 DAS }\end{array}$ & $\begin{array}{c}\text { No. of total } \\
\text { inflorescence at 3 DAS }\end{array}$ & \% infestation \\
\hline$P_{1}$ & 23.35 & $5.98 \mathrm{~cd}$ & 29.33 & $20.53 \mathrm{c}$ \\
\hline $\mathrm{P}_{2}$ & 22.07 & $8.26 \mathrm{~b}$ & 30.33 & $27.32 \mathrm{~b}$ \\
\hline $\mathrm{P}_{3}$ & 24.52 & $6.14 \mathrm{c}$ & 30.67 & $20.10 \mathrm{c}$ \\
\hline $\mathrm{P}_{4}$ & 23.00 & $4.99 \mathrm{~d}$ & 28.00 & $18.89 \mathrm{c}$ \\
\hline $\mathrm{P}_{5}$ & 25.86 & $5.14 \mathrm{~cd}$ & 31.00 & $16.69 \mathrm{c}$ \\
\hline $\mathrm{P}_{6}$ & 22.68 & $8.65 \mathrm{~b}$ & 31.33 & $27.57 \mathrm{~b}$ \\
\hline $\mathrm{P}_{7}$ & 21.66 & $10.67 \mathrm{a}$ & 32.33 & $33.09 \mathrm{a}$ \\
\hline $\mathrm{CV}(\%)$ & 12.49 & 7.97 & 10.02 & 11.06 \\
\hline
\end{tabular}


Means within a column followed by same letter(s) do not differ significantly $(\mathrm{P}=0.05)$ according to Duncan's Multiple Range Test (DMRT).

$\mathrm{P}_{1}=$ Mechanical control (hand picking) and 4 sprays of neem leaf extract @ 50 $\mathrm{g}^{-1}$ of water at 7 days interval

$\mathrm{P}_{2}=4$ sprays of biskatali leaf extract @ $50 \mathrm{~g} \mathrm{l}^{-1}$ of water at 7 days interval

$\mathrm{P}_{3}=4$ sprays of sabion $60 \mathrm{EC}$ (diazinon) @ $1 \mathrm{ml}^{-1}$ of water at 7 days interval

$\mathrm{P}_{4}=$ Mechanical control (handpicking) and 4 sprays of admire $50 \mathrm{SP}$ (imidacloprid) @ $1 \mathrm{ml} \mathrm{l}^{-1}$ of water at 7 days interval

$\mathrm{P}_{5}=$ Mechanical control (handpicking) and 4 sprays of ripcord $10 \mathrm{EC}$ (cypermethrin) @ $1 \mathrm{ml} / \mathrm{l}$ of water at 7 days interval
$\mathrm{P}_{6}=$ Mechanical control (handpicking) and 4 sprays of neem oil @ $5 \mathrm{ml}^{-1}$ of water at 7 days interval

$\mathrm{P}_{7}=$ Control

Among the packages the highest reduction percent of inflorescence infestation by aphid per plot over control was found in $\mathrm{P}_{5}(49.56 \%)$ followed by $\mathrm{P}_{4}$ (42.91\%), $\mathrm{P}_{3}(39.25 \%)$ and $\mathrm{P}_{1}(37.95 \%)$ (Fig. 1). On the other hand, the lowest reduction of percent inflorescence infestation by aphid over control was found in package $\mathrm{P}_{6}(16.68 \%)$. So, the package $\mathrm{P}_{5}$ performed better than all other treatments in reducing the percent aphid infestation of inflorescence per plot by aphids.

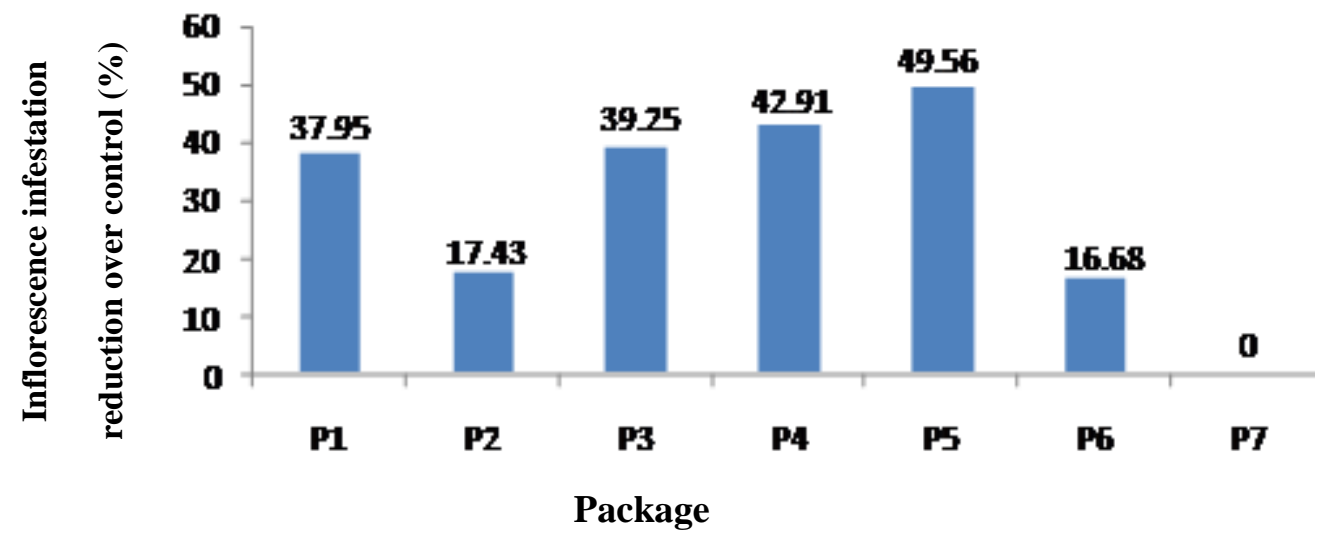

Fig. 1. Effect of different IPM packages on the reduction (\%) of number of infested inflorescence per plot by aphids

Effect of different IPM packages in suppressing pod borer in terms of number of pods per plot

The effect of different IPM packages in suppressing pod borer infestation in country bean is presented in Table 2. It has been shown that there were significant differences in the infestation levels of pod borer attacking country bean due to application of different IPM packages.

Among IPM packages in the experiment, the highest number of healthy podper plot was recorded in $\mathrm{P}_{5}$ (1417) which was statistically similar to that of $\mathrm{P}_{6}(1267)$. On the other hand, the lowest number of healthy podper plot was recorded (738.8) in untreated control plot $\left(\mathrm{P}_{7}\right)$ which was statistically comparable to those of $\mathrm{P}_{2}(865.5)$ and $\mathrm{P}_{3}$ (831.3). Number of healthy pods per plot recorded on $\mathrm{P}_{1}$ (1118) and $\mathrm{P}_{4}$ (1053) showed intermediate result which were not statistically different from each other.

The highest number of infested podper plot was recorded in $\mathrm{P}_{7}$ (110.6) which was untreated control plot and statistically different from those of all other packages. On the other hand, the lowest number of infested podper plot was recorded in $\mathrm{P}_{1}$ (63.38) which was statistically similar to those of $\mathrm{P}_{2}$ (72.13), $\mathrm{P}_{4}$ (74), $\mathrm{P}_{5}$ (67.58) and $\mathrm{P}_{6}$ (70.50). Number of infested pod borer $\operatorname{inP}_{3}$ (88.17) showed intermediate level which was statistically identical to that of $\mathrm{P}_{4}$ (74.00)

In case of percent of pod infestation by pod borer in number, it was found significantly the highest percentage of infestation was recorded $\operatorname{inP}_{7}$ (13.21) which significantly different from those of all other packages. This was followed by $\mathrm{P}_{3}(9.59)$ and $\mathrm{P}_{2}$ (7.75) and they were statistically similar. The lowest percent of pod infestation was in $\mathrm{P}_{5}(4.59)$ but the infestations of pods were statistically identical to those of package $\mathrm{P}_{1}$ (5.38), $\mathrm{P}_{4}$ (6.57) and $\mathrm{P}_{6}$ (5.28). It is found that $\mathrm{P}_{5}$ comprising mechanical control (hand picking) and 4 sprays of ripcord $10 \mathrm{EC} @ 1 \mathrm{ml} \mathrm{l}^{-1}$ of water applied at 7 days interval, performed better in suppressing pod borer infestation. 
Table 2. Effect of different IPM packages in suppressing pod borer in terms of number of pods per plot

\begin{tabular}{|c|c|c|c|c|}
\hline \multirow[t]{2}{*}{ Treatments } & \multicolumn{4}{|c|}{ Pod per plot number } \\
\hline & Healthy & Infested & Total & $\%$ infestation \\
\hline $\mathrm{P}_{1}$ & $1118 \mathrm{bc}$ & $63.38 \mathrm{c}$ & 1182 & $5.38 \mathrm{~cd}$ \\
\hline $\mathrm{P}_{2}$ & $865.5 \quad d$ & $72.13 \mathrm{c}$ & 937.6 & $7.75 \mathrm{bc}$ \\
\hline $\mathrm{P}_{3}$ & $831.3 \quad \mathrm{~d}$ & $88.17 \mathrm{~b}$ & 919.4 & $9.59 \mathrm{~b}$ \\
\hline $\mathrm{P}_{4}$ & $1053 \mathrm{c}$ & $74.00 \mathrm{bc}$ & 1127 & $6.57 \mathrm{~cd}$ \\
\hline $\mathrm{P}_{5}$ & 1417 a & $67.58 \mathrm{c}$ & 1485 & $4.59 \mathrm{~d}$ \\
\hline $\mathrm{P}_{6}$ & $1267 \mathrm{ab}$ & $70.50 \quad c$ & 1338 & $5.28 \mathrm{~cd}$ \\
\hline $\mathrm{P}_{7}$ & $738.8 \quad \mathrm{~d}$ & $110.6 \mathrm{a}$ & 849.5 & $13.21 \mathrm{a}$ \\
\hline $\mathrm{CV}(\%)$ & 10.02 & 10.78 & 9.14 & 10.83 \\
\hline
\end{tabular}

Means within a column followed by same letter(s) do not differ significantly $(\mathrm{P}=0.05)$ according to Duncan's Multiple Range Test (DMRT).

The percent of reduction of pod infestation by pod borer in number over control per plot of different IPM packages is shown in Fig. 2. It revealed from the figure that among the IPM packages, the highest reduction of percent of pod infestation over control was in the plot of package $\mathrm{P}_{5}(65.20)$ followed by $\mathrm{P}_{6}(60.01)$ and $\mathrm{P}_{1}$ (59.27).

The percent of reduction of pod infestation over control was the lowest in the package $\mathrm{P}_{3}(27.38)$ followed by $\mathrm{P}_{2}$ (41.27) and $\mathrm{P}_{4}$ (50.26). It is clear that all the packages performed better than the control treatment but $\mathrm{P}_{5}$ was found to be the best for the suppression of pod borer in country bean.

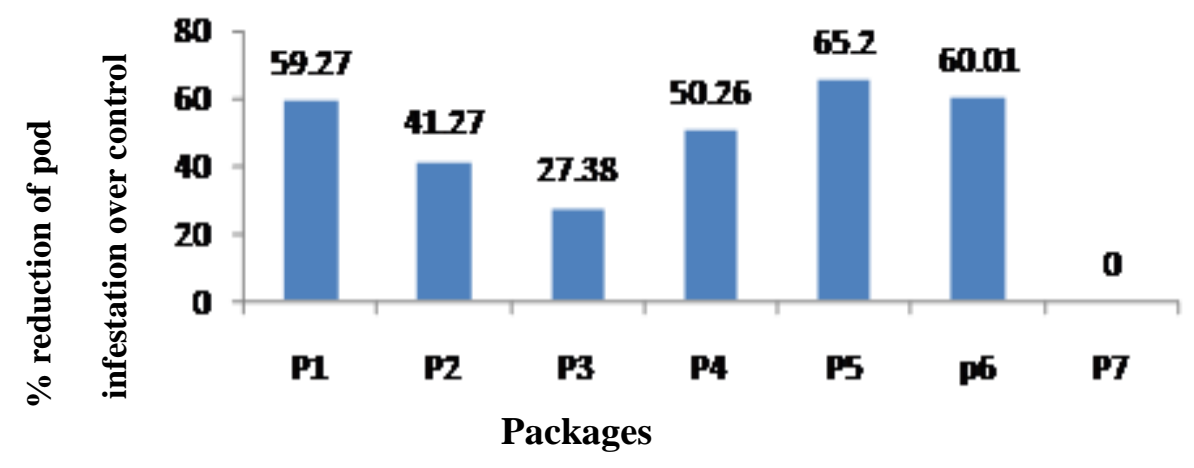

Fig. 2. Effect of different IPM packages on \% reduction of number of infested pod per plot over control in suppressing pod borer of summer country bean (BARI Seem-3)

Effect of IPM packages on yield $\left(\mathrm{t} \mathrm{ha}^{-1}\right)$ of summer country bean (BARI Seem 3)

The yield $\left(\mathrm{t} \mathrm{ha}^{-1}\right)$ of country bean from the plots of different IPM packages are shown in Table 3.The marketable yield $\left(\mathrm{t} \mathrm{ha}^{-1}\right)$ of country been obtained from the plots used different IPM packages was range from 6.57-11.64 $\mathrm{tha}^{-1}$.

Among different IPM packages in the study, the highest marketable yield was recorded in the plots of $\mathrm{P}_{5}\left(11.64 \mathrm{t} \mathrm{ha}^{-1}\right)$ which was statistically identical that of with $\mathrm{P}_{6}\left(11.58 \mathrm{tha}^{-1}\right)$ and $\mathrm{P}_{4}\left(10.74 \mathrm{t} \mathrm{ha}^{-1}\right)$ but significant different from all other packages. On the other hand, the lowest marketable yield was recorded in $\mathrm{P}_{7}\left(6.57 \mathrm{t} \mathrm{ha}^{-1}\right)$ i.e., untreated control plot which was statistically different from all the packages.
Among different IPM packages used in the study, the highest total yield $\left(12.50 \mathrm{tha}^{-1}\right)$ was recorded in $\mathrm{P}_{5}$ consist of mechanical control (handpicking) and 4 sprays of ripcord $10 \mathrm{EC}$ (cypermethrin) @ $1 \mathrm{ml} \mathrm{l}^{-1}$ of water at 7 days interval which was statistically identical with $\mathrm{P}_{6}\left(12.33 \mathrm{t} \mathrm{ha}^{-1}\right)$ and also with $\mathrm{P}_{4}$ $\left(11.49 \mathrm{t} \mathrm{ha}^{-1}\right)$. On the other hand, the lowest total yield $\left(8.43 \mathrm{t} \mathrm{ha}^{-1}\right)$ was recorded in untreated plot $\mathrm{P}_{7}$ which was statistically similar to that of $\mathrm{P}_{1}(9.62 \mathrm{t}$ $\left.\mathrm{ha}^{-1}\right)$, and $\mathrm{P}_{2}\left(8.94 \mathrm{tha}^{-1}\right) . \mathrm{P}_{3}\left(9.43 \mathrm{t} \mathrm{ha}^{-1}\right)$ and these was showed intermediate level of yield but statistically similar to that of $\mathrm{P}_{4}(11.49)$.

Relationship between pod borer infestation and marketable yield of summer country bean (BARI Seem-3)

Fig. 3 represents the relationship between percent pod infestation and marketable yield of summer country 
bean. It revealed that pod infestation is negatively correlated with marketable yield of country bean. The relationship was significant and about $20.6 \%$ yield would be affected due to pod borer infestation.

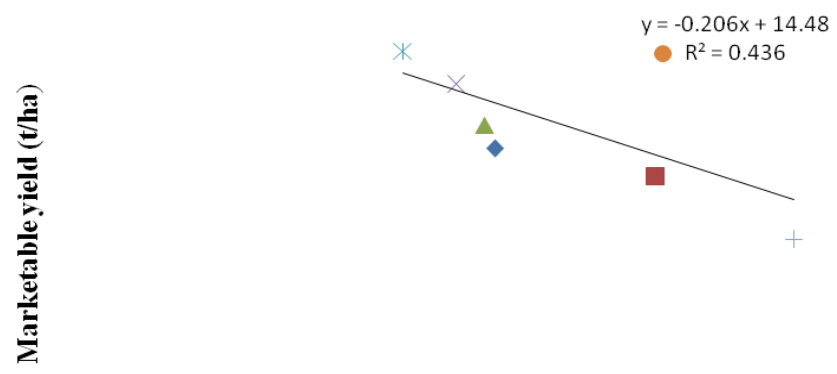

$\%$ pod infestation

Fig. 3. Relationship between percent pod infestation and marketable yield of summer country bean (BARI Seem-3)

\section{Economic analysis}

Gross return (Tk ha $\left.{ }^{-1}\right)$

Table 4 showed that the highest gross return was found in $\mathrm{P}_{5}\left(407400.00 \mathrm{Tk} \mathrm{ha}^{-1}\right)$. On the other hand, the lowest gross return was found in $\mathrm{P}_{7}\left(230055.00 \mathrm{Tk} \mathrm{ha}^{-1}\right)$. The gross return obtained from $\mathrm{P}_{1}$ (315595.00Tk ha- $\left.{ }^{-1}\right), \mathrm{P}_{2}$ (323995.00Tk ha $\left.\mathrm{ha}^{-1}\right), \mathrm{P}_{3} \quad\left(302750.00 \quad \mathrm{Tk} \quad \mathrm{ha}^{-1}\right), \quad \mathrm{P}_{4}$
(375900.00 Tk ha ${ }^{-1}$ ) and $\mathrm{P}_{6}\left(405300.00 \mathrm{Tk} \mathrm{ha}^{-1}\right)$ was less than $\mathrm{P}_{5}$ but higher than $\mathrm{P}_{7}$ (Table 4).

\section{Net return $\left(\mathrm{Tk} \mathrm{ha}^{-1}\right)$}

As shown in Table 7 the highest net return was recorded in $\mathrm{P}_{5}\left(373836.00 \mathrm{Tk} \mathrm{ha}^{-1}\right)$. On the other hand, the lowest net return was calculated in $\mathrm{P}_{7}\left(230055.00 \mathrm{Tk} \mathrm{ha}^{-1}\right)$. The net return obtained from $\mathrm{P}_{1}\left(285699.00 \mathrm{Tk} \mathrm{ha}^{-1}\right), \mathrm{P}_{2}$ $\left(266299.00 \mathrm{Tk}^{\mathrm{Ta}} \mathrm{h}^{-1}\right), \mathrm{P}_{3}\left(284230.00 \mathrm{Tk} \mathrm{ha}^{-1}\right), \mathrm{P}_{4}$ $\left(342180.00 \mathrm{Tk} \mathrm{ha}^{-1}\right)$ and $\mathrm{P}_{6}\left(368560.00 \mathrm{Tk} \mathrm{ha}^{-1}\right)$ was less than that of $\mathrm{P}_{5}$ but higher than $\mathrm{P}_{7}$ (Table 4).

\section{Adjusted net return ( $\left.\mathrm{Tk} \mathrm{ha}^{-1}\right)$}

From the Table 4, it was observed that numerically the highest adjusted net return was found in $\mathrm{P}_{5}(143781.00$ $\mathrm{Tk} \mathrm{ha}^{-1}$ which was higher than all other packages. On the other hand, the lowest adjusted net return was obtained in $\mathrm{P}_{2}\left(36244 \mathrm{Tk} \mathrm{ha}^{-1}\right)$. The adjusted net return obtained from $\mathrm{P}_{1}\left(55644.00 \mathrm{Tk} \mathrm{ha}{ }^{-1}\right), \mathrm{P}_{3}\left(54175.00 \mathrm{Tk} \mathrm{ha}^{-1}\right), \mathrm{P}_{4}$ $\left(112125.00 \mathrm{Tk} \mathrm{ha}^{-1}\right)$ and $\mathrm{P}_{6}\left(138505.00 \mathrm{Tk} \mathrm{ha}^{-1}\right)$ was less than $\mathrm{P}_{5}$ but higher than treatment $\mathrm{P}_{2}$ (Table 3 ).

\section{Benefit cost ratio (BCR)}

Considering the management of pod borer of country bean, the highest benefit cost ratio was obtained from $\mathrm{P}_{5}$ (4.28) followed by $\mathrm{P}_{6}$ (3.76) and $\mathrm{P}_{4}$ (3.32). On the other hand, the lowest benefit cost ratio (1.59) was obtained from the $\mathrm{P}_{2}$ followed by $\mathrm{P}_{3}(2.9)$ and $\mathrm{P}_{1}(1.8)$ (Table 4). Hence the $\mathrm{P}_{5}$ was found to be the most economic approach among the packages studied for suppression the pod borer in country bean.

Table 3. Benefit cost ratio analysis of various IPM packages for the suppression of pod borer in summer country bean (BARI Seem-3)

\begin{tabular}{|l|l|l|l|l|l|l|}
\hline \multicolumn{1}{|c|}{ Treatment } & \multicolumn{1}{|c|}{$\begin{array}{c}\text { Management } \\
\text { cost (Tk) }\end{array}$} & Yield (t ha $\left.{ }^{-1}\right)$ & $\begin{array}{c}\text { Gross return } \\
(\mathbf{T k})\end{array}$ & $\begin{array}{c}\text { Net return } \\
\text { (Tk) }\end{array}$ & $\begin{array}{c}\text { Adjusted net } \\
\text { return (Tk) }\end{array}$ & \multicolumn{1}{c|}{ BCR } \\
\hline $\mathrm{P}_{1}$ & 29896.00 & $9.017 \mathrm{c}$ & 315595.00 & 285699.00 & 55644 & 1.86 \\
\hline $\mathrm{P}_{2}$ & 22696.00 & $8.257 \mathrm{bc}$ & 288995.00 & 266299.00 & 36244 & 1.59 \\
\hline $\mathrm{P}_{3}$ & 18520.00 & $8.65 \mathrm{ab}$ & 302750.00 & 284230.00 & 54175 & 2.9 \\
\hline $\mathrm{P}_{4}$ & 33720.00 & $10.74 \mathrm{ab}$ & 375900.00 & 342180.00 & 112125 & 3.32 \\
\hline $\mathrm{P}_{5}$ & 33564.00 & $11.64 \mathrm{a}$ & 407400.00 & 373836.00 & 143781 & 4.28 \\
\hline $\mathrm{P}_{6}$ & 36740.00 & $11.58 \mathrm{a}$ & 405300.00 & 368560.00 & 138505 & 3.76 \\
\hline $\mathrm{P}_{7}$ & 0.00 & $6.573 \mathrm{~d}$ & 230055.00 & 230055.00 & 0.00 & 0.000 \\
\hline $\mathrm{CV}(\%)$ & & 8.31 & - & & & - \\
\hline
\end{tabular}

\section{References}

Alam, M. Z. 1969. Insect Pests of Vegetables and Their Control in East Pakistan. The Agriculture Information Service, Department of Agriculture;3, R.K. Mission Road, Dhaka- 3, East Pakistan, $146 \mathrm{p}$.

Anonymous. 2004. Year Book of Agricultural Statistics of Bangladesh. Bangladesh Bureau of Statistics, Ministry of Planning, Government of the People's
Republic of Bangladesh, Dhaka, Bangladesh. $106 \mathrm{p}$.

Anonymous. 2010.Statistical Year book of Bangladesh 2010.Bangladesh Bureau of Statistics. Statistics Division, Ministry of planning, Government of the People's Republic of Bangladesh, Dhaka, Bangladesh.

Begum, R. A. 1993.Techniques of growing legume vegetable. In: Intensive vegetable growing and its utilization. A compilation of lecture materials of 
training course held in BARI, Gazipur, Bangladesh. 22-25 November 1993, 94p.

Dixon, A. F. G. 1987. Parthenogenetic reproduction and rate of increase in aphid. pp. 269-287.In Minks.A.K.and P.Harrewijn (eds) Aphids their biology, natural enemies and control. Elsevier, Amsterdam.

Gopalan, C. V; Ramasastri, B. Y. and Balasnbramarun, S. C. 1982.Nutritive values of Indian food. National institute of nutrition, ICMR, Hyderabad. $75 \mathrm{p}$.

Hossain, A. and Awrangzeb, S. N. H. 1992. Vegetable production policies, plans and future directions. pp. 21-30

Islam, M. S. 2008.Genetic diversity, combining ability and heterosis in Hyacinth bean [(Lablab purpureus (L) Sweet]. A phd dissertation submitted to Bangabandhu Sheikh Mujibur Rahman Agricultural University, Salna, Gazipur. Bangladesh, $190 \mathrm{p}$.

Kalra, V. K. 1979. Integrated control of the pest complex of mustard. Ph.D. Thesis submitted to the Dept. of Entomology, Haryana Agril. Univ. Hisar, India.

Karim, M. A. 1995. Management of insect pests of vegetables. In: Vegetables.In : M.L.Chadha, K.U. Ahmad, S. Shanmugasundaram and A. Quasem 1995.(eds.) Vegetable Crops Agribusiness. Proceedings of a workshop held at BARC, Dhaka, Bangladesh 2-4 May 1995. AVRDC,BARC and BARI.

Schaaffhausen, R. V. 1963. Dolichos lablab or Hyacinth bean-its use for feed, food and soil improvements. Econ. Bot., 17: 146-153

Sharma, H. C. 1998. Legume pod borer. Maruca vitruta: Insect plant relationships. Insect Sci. Applic., 204.

Walter, J. F. 1999.Commercial experience with neem products. In: Methods in Biotechnology.5: Biopesticide. Ed. by Hall,F.R.;Menn, J.J.Totowa, NJ:Humana Press, pp 155-170. 